\title{
THE PIGMENT GRANULES IN THE COMPOUND EYES OF DROSOPHILA
}

\author{
D. J. NOLTE \\ Department of Zoology, University of the Witwatersrand
}

Received 5.ix.6o

\section{INTRODUCTION}

THE compound eyes of Drosophila contain two kinds of pigment, a red pigment soluble in water and a brown pigment soluble in acidic methanol. These pigments are concentrated in granular form in four main regions of the eye, these being the primary cells, the proximal and basal regions of the secondary cells, and the post-retinal region. In previous studies (Nolte, I950, I954) it was postulated that both pigments are generally deposited in the same granules. An electron microscope study has, however, yielded fresh data in regard to the structure of the compound eye and the presence of further concentrations of pigment (Nolte, I96I). In view of these facts it was thought necessary to re-examine the eyes of the wild type and eye-mutants of two species in order to re-assess the action of various eye-colour genes in the eye-pigmentary system of Drosophila.

\section{MATERIAL AND METHOD}

The eyes were used from adults and pupæ of the wild-type flies and also from a number of eye-colour mutant stocks of the two species which were used, as follows. For D. melanogaster: the Canton-S and Graaff-Reinet wild type strains; the mutants scarlet $(s t)$, vermilion $(v)$, brown $(b w)$, sepia $(s e)$, clot $(c l)$, pink $(p)$, mahogany (mah), prune (pn), raspberry ${ }^{2}\left(r a s^{2}\right)$, brown scarlet (bw st), white $(w)$, white-tinged $\left(w^{t}\right)$, white-apricot $\left(w^{a}\right)$, white-eosin $\left(w^{b}\right)$, white-cherry $\left(w^{c h}\right)$, whiteblood $\left(w^{b l}\right)$, white-coral $\left(w^{c o}\right)$, white-wine $\left(w^{w}\right)$, white-coloured $\left(w^{c o l}\right)$, whitesatsuma $\left(w^{s a t}\right)$; the pupæ of the wild type, mah, $w^{c o}, w$. For $D$. pseudoobscura: the chromosome races Chiricahua and Santa Gruz of the wild type; the mutants vermilion (v), purple (pr), sepia (se).

The heads of one-day-old flies and of pupæ of various ages were fixed for 24 hours in chilled 2 per cent. osmium tetroxide buffered with an equal volume of acetateveronal. Dehydration was carried out in dioxan for periods of 18-24 hours, with a final dehydration in absolute methanol for $\frac{1}{2}$ hour. The heads were embedded in $n$-butyl methacrylate in the usual manner. Sections of from 200 to $500 \AA$ were cut by means of a diamond knife with a Porter-Blum microtome, and micrographs were made in a Siemens Ioo KV Elmiscope. The electron micrographs were used to calculate the diameters of the various kinds of pigment granules. In determining the relative sizes of these granules, ranges of variation could not be determined in electron micrographs, but the diameters of the largest granules found in each region were calculated. In some sections it was found that for a particular region there were a number of granules of the same size, and where variation in size exists this could generally be detected by means of the light microscope. The diameters given in table $\mathrm{I}$ are thus averages of the largest diameters found in each case. 


\section{OBSERVATIONS}

The structure of the eye of Drosophila is shown in text-fig. $\mathrm{r}$, indicating the various regions in which pigment granules occur. The diameters of these granules are given in table I, together with the relative amounts of the two pigments that were obtained for these

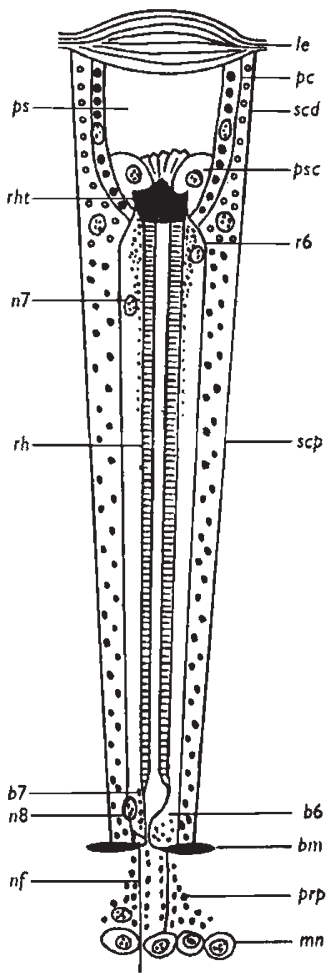

TexT-prG. I.-A diagrammatic representation of a longitudinal section of one ommatidium of the compound eye of Drosophila. $b m$, basement membrane ; $b 6$, dilated base of normal retinula; $b 7$, base with dense cytoplasm and granules of the seventh, displaced retinula ; le, lens ; $m n$, monopolar neurons ; $n f$, nerve fibre ; $n 7$, nucleus of displaced retinula ; $n 8$, nucleus of reduced eighth retinula ; $p c$, primary pigment cell ; $p r p$, post-retinal pigment granules ; $p s$, pseudocone ; psc, pseudocone cell ; $r 6$, normal retinula with small pigment granules distally; $r h$, rhabdomere; $r h t$, non-crystalline tips of rhabdomeres ; scd, distal part of secondary pigment cell ; scp, proximal part of secondary pigment cell.

strains in previous investigations (Nolte, 1952-1959). These amounts are presented as photometric absorption for similar numbers of heads in equal amounts of the extraction fluids, AEA or acidified 30 per cent. ethanol for the red pigment, and AMA or acidified methanol for the brown pigment.

In the wild type of $D$. melanogaster the granules in the primary pigment cell are electron-dense, smooth-surfaced, globular masses (plate, fig. I). In the secondary pigment cell the distal part, up to the level of the nucleus, carries a slightly greater frequency of granules which most often show up as hollows with a thin rim of electron-dense 


\begin{tabular}{|c|c|c|c|c|}
\hline \multirow{11}{*}{ 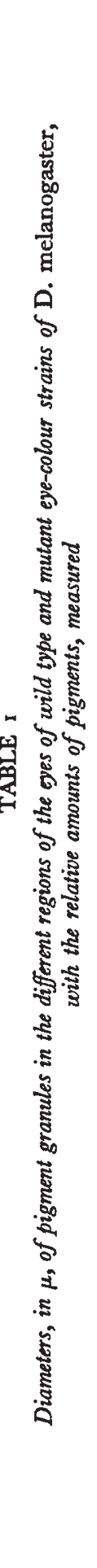 } & \multirow{2}{*}{ 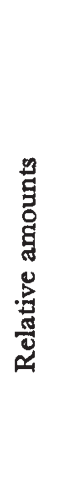 } & \multicolumn{2}{|c|}{ 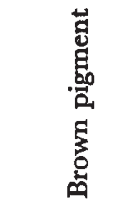 } & 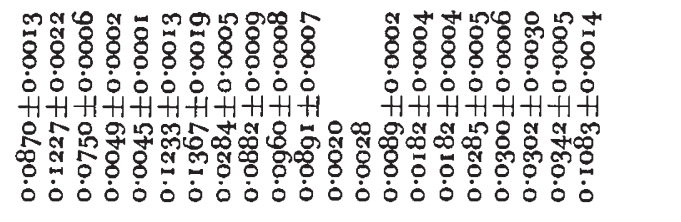 \\
\hline & & \multicolumn{2}{|c|}{ 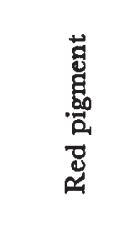 } & 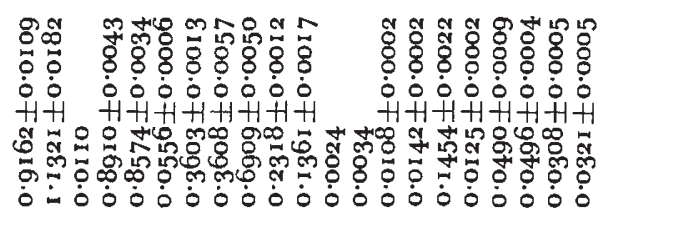 \\
\hline & \multirow{3}{*}{ 莺 } & \multicolumn{2}{|c|}{ 超 } & 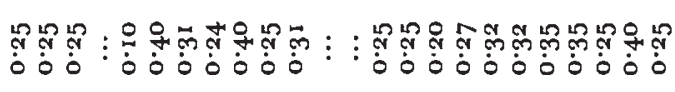 \\
\hline & & \multicolumn{2}{|c|}{ 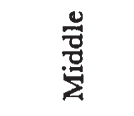 } & 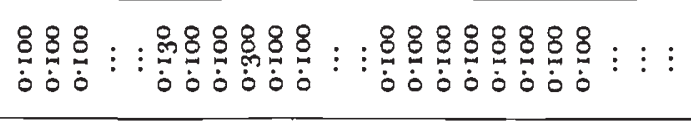 \\
\hline & & \multicolumn{2}{|c|}{ 葪 } & 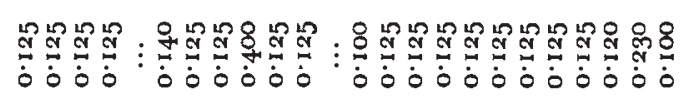 \\
\hline & & & & 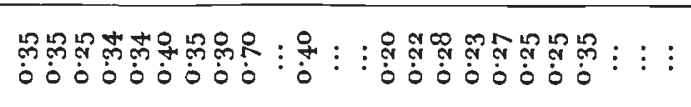 \\
\hline & & & 零 & 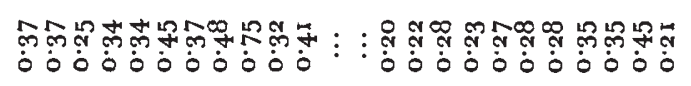 \\
\hline & 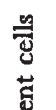 & 宽 & 密 & 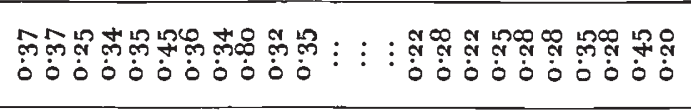 \\
\hline & 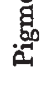 & & 丞 & 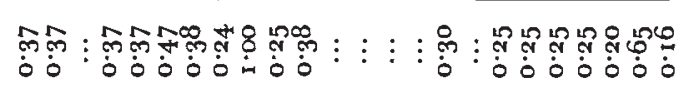 \\
\hline & & & . & 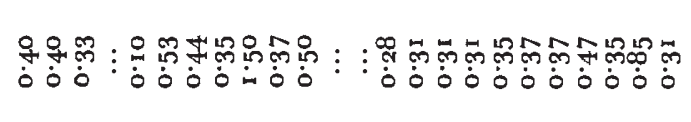 \\
\hline & & & & 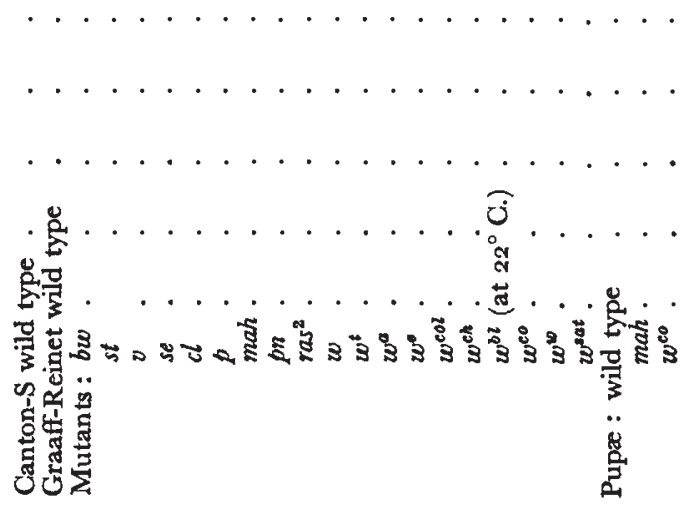 \\
\hline
\end{tabular}


material. In the middle region the granules of the secondary cell are electron-dense but with uneven outlines and sometimes a hollow to one side. In the basal region of the secondary cell the same type of granule is found in greater numbers (plate, fig. 2). All the granules of the post-retinal region are similar to the previous, and near the layer of monopolar neurons they occur in the same frequency as in the secondary cell bases. In the retinular cell small, dense, rounded granules are clustered distally near the rhabdomere, just underneath its homogeneous tip (Nolte, I96I); more proximally the frequency of these granules decreases, and basally they more or less disappear. The base of the retinula is dilated, and these bases of the six normal retinulæ block the lower end of the rhabdome (Nolte, 196I). In these bases larger granules of the same type as in the retinula tips are distributed at about half the frequency of the latter. In the base of the seventh, or displaced, retinula, where it fits against the reduced eighth retinula, dense granules with an average diameter of $0.15 \mu$ are found in a single layer in cytoplasm which appears to be more electron-dense than that of the other retinulæ.

In the wild type pupa, at about 8 o hours after puparium formation, the granules are of the same type as in the adult (plate, fig. 3 ), with the exception of those in the distal part of the secondary cell which are only about half the size of the adult granules, and differ further in that they are solid and constituted of a medium electron-dense material.

In the mutant $b w$ the granules are all of the electron-dense type, but somewhat smaller than normal in size in the primary and secondary cells, though in the normal frequency. In the distal part of the secondary cell, however, no granules occur down to the level of the nucleus. In the mutants st and $v$ (plate, figs. 4 and 5) no granules occur in the primary cell excepting for a few small electron-dense granules in $v$. In the whole of the secondary cell and in the postretinal region the normal frequency of granules is found, but all are of the hollowed-out type; in st a few large hollows (diameter about $0.5^{\circ} \mu$ ) occur in the distal part of the secondary cell near the nucleus. Granules are absent from the retinule excepting for a few electrondense granules in the distal tips in st and a few of the same type in the bulbous bases of the six normal retinulx of $v$.

The brown pigment is an ommatin of the ommochrome group and is insoluble in water. Following on the initial work of Beadle and Ephrussi (1936, 1937) on transplantation of eye buds in larvæ of Drosophila, it became known that the brown pigment is derived from tryptophan through stages of oxidation to formylkynurenine, kynurenine and 3-hydroxykynurenine (the brown chromogen). In the mutant $v$, in which very little brown pigment is formed, Green (1949) has shown that free tryptophan is accumulated. According to Becker (1942) the ommatins combine with protein to form chromoproteins. In the moth Ephestia kühniella a related brown pigment, 
skotommin, is believed by Caspari (1 949 ) to be deposited in granules of which the precursor is possibly ribonucleic acid. This does not appear to be the case with Drosophilids. The data of the present study show that, since bw produces only brown pigment and st and $v$ very little, the brown pigment is deposited in the electron-dense granules which occur in all regions of the eye with the exception of the distal part of the secondary cell. It is also evident that brown pigment only is deposited in the primary cells and the retinulæ.

The water-soluble red pigment is a pteridine (Viscontini, Hadorn and Karrer, 1957). By means of a chromatographical technique Hadorn and Mitchell (195I) showed that fluorescent substances, later identified as pteridines, are present in D. melanogaster. Various types of pteridines are concentrated in the eye, body fluid, testes and malpighian tubes, and striking changes in concentration occur at different stages of development. Several of these substances are closely related, genetically and biochemically, to the red eye pigment. During studies by Forrest and Mitchell (1955), Viscontini et al. (1955, 1957), Ziegler-Günder and Hadorn (1958) these pteridines were named drosopterin (DP, the red pigment), pteridine-6-carboxylic acid (PC), iso-xanthopterin (IX), sepiapterin (SP), and the HBpteridines (2-amino-4-hydroxypteridine and biopterin). The chemical structures of PC, IX, SP and HB were determined by Forrest and Mitchell (1954, 1955). In Drosophila the pigment pteridines are not in crystalline form but are bound to proteins, polypeptides or nucleoproteins according to Ziegler-Günder (1956). Various theories were formulated in regard to the biochemical interrelations of these pteridines; for example, Forrest and Mitchell (1955) visualised the conversion of uric acid into isoxanthopterin, and the further conversion of this into one of the HB-pteridines which could then be degraded into $\mathrm{PC}$, this being regarded as the logical precursor of SP which in turn could be a precursor of DP, the red pigment. On the other hand, Taira and Nawa (1958) find that, although uric acid is regarded as being the final product of purine metabolism, the production of uric acid seems to be independent of the increase in amount of pteridines during metamorphosis. The present study shows that the hollowed-out granules in the distal tip of the secondary cell of the wild type, and in the whole secondary cell and post-retinal region of $s t$ and $v$, must have carried only red pigment. This shows a varying amount of loss depending on, for example, the period of contact of the sections with the acetone-water on to which they are floated. Although it had been postulated (Nolte, 1950, 1955) that all the granules were non-specific, i.e. contained both pigments, it now appears highly probable that only the granules in the middle and basal regions of the secondary cell and in the post-retinal region carry both pigments. In these regions the granules are larger in the wild type than in the mutants $b w$, st and $v$ although present in the same frequency-the 
irregular outlines of the granules in these regions in the wild type may be due to partial loss of pigment (the red component).

Deposition of the pigments seems to proceed in a centrifugal manner, that of the brown being initiated earlier than that of the red pigment (Nolte, 1950, 1955; Clayton, 1959). In the wild type pupa it is now seen that the granules in the distal tip of the secondary cell are still relatively small, in addition to containing a material differing in electron-density from those in the adult, while the other granules in the secondary cell are progressively larger the nearer they are located to the basement membrane. It thus seems probable that the brown pigment is the first to be deposited in the basal granules, that the red pigment is added subsequently, and that it is deposited perhaps mixed with a small amount of brown pigment, on the surface of the growing granule.

A phenomenon that has not been definitely resolved in this investigation is that of the presence of greater numbers of the small ommochrome granules in the proximal region of the pupal retinula than in the adult: it is conceivable that some measure of photoreaction of these granules exists.

The submicroscopic structure of the eyes of the other mutant eye-colour strains may be described by taking them in groups. The first group consists of $s e$ and $c l$ (plate, fig. 6) in which the ommochrome granules in the primary cell are larger than normal. In the distal part of the secondary cell the granules are not hollowed but are of medium electron-density and have a fuzzy outline; in $\mathrm{cl}$ some of these granules seem to be emptied of part of their contents. The small ommochrome granules of the distal part of the retinulæ extend proximally in greater numbers than normally. In se all granules are larger than normal. In the mutant se the yellow form of the red pigment which has been called sepiapterin is found (Nolte, 1954b); the medium dense granules of the distal region of the secondary cell should contain sepiapterin, which thus seems less soluble and liable to loss than drosopterin. In the mutant $c l$ both drosopterin and sepiapterin occur (Nolte, r $954^{b}$ ) and those granules which seem to be emptied of part of their contents presumably indicate the loss of the drosopterin part of a mixture of the two pteridines.

The second group of mutants consists of $p$ and mah (plate, fig. 7) which show granule abnormalities. In $p$ some of the granules of the secondary cell, especially in the basal region, appear to be double, i.e. they are composed of a dense core and a less dense cortex. In mah granules much larger than normal, but less in number, are found in all the cells. In the pupa, at about 70 hours after puparium formation, the granules are already more than half the adult size, and in both the pupa and the adult the granules in the distal part of the secondary cell are not emptied of their contents but are of a medium density. In the adult very few granules occur in the post-retinal region, and none in this region in the 70 hour pupa. 
The third group of mutants consists of $p n$ and $r a s^{2}$ in which a disorientation of the secondary pigment cell region occurs (Nolte, I950, 1955), these cells apprently being drawn away from the basement membrane. In electron micrographs it is seen that in $p n$ parts of some rhabdomes are not sheathed by secondary cells but merge with parts of adjacent rhabdomes. In ras $^{2}$ the secondary cells form bulges at various places around the rhabdomes. In both mutants the distal part of the secondary cell contains granules with a low density; more proximally in this cell the granules are denser but with a roughish surface in $p n$, and irregular in shape and with a roughish or fuzzy outline in $\mathrm{ras}^{2}$. In the bulges of the secondary cell the granules are clumped together in great numbers. The post-retinal regions have very few granules.

The last group of mutants comprises the multiple alleles of white, in which the decrease in pigmentation is not correlated with a decrease in size and number of all the different types of granules. In the primary cell the dense granules are absent in $w^{t}$ and $w$, decreased in number in $w^{a}$, but occur in normal frequency in the other alleles. In $w$ no retinular granules are present, in $w^{t}$ only a few very small granules occur in the distal tips of retinulæ, while in the other alleles distal and basal granules are present in the retinulæ, the sizes for the basal granules varying as shown in table $\mathrm{I}$. The basal granules are more tightly packed in $w^{b l}, w^{c o}, w^{w}$ and $w^{c}$ because the retinular bases are apparently smaller in these alleles. In the allele $w^{c o l}$ the small ommochrome granules in the base of the seventh retinula are smaller in size but greater in number than is normally the case (plate, fig. 8). In the basal and middle parts of the secondary cell the granules get smaller and decrease in number with decrease in pigmentation. In the distal part of the secondary cell the granules are of various types; in the upper members of the series the smaller granules are electron-dense while larger granules are of uneven density and with a fuzzy outline. In the lower members of the series a few medium dense bodies occur in this region, with a diameter of up to $\mathrm{I} \cdot 0 \mu$ in $w^{b}$ and $w^{c h}$, and up to $\mathrm{I} \cdot 2 \mu$ in $w^{a}$, in which some of the granular masses are compound (plate, fig. 9). In $w^{t}$ and $w$ a number of medium dense, often compound, granular masses are distributed throughout the primary and secondary cells, but especially the latter, the largest in the distal part of the secondary cell having diameters of up to $0.8 \mu$. In the pupa of $w$, about 80 hours after puparium formation, these granules are already present in the secondary cell, though somewhat smaller.

The combination brest has a colourless eye in which the primary and secondary cell present a submicroscopic picture very similar to that of $w$.

In $D$. pseudoobscura the structure of the eye is in all essentials similar to that of $D$. melanogaster. In the primary cell of the wild type the ommochrome granules are larger than in the latter species, with 
diameters of $0.44 \mu$ in the distal region and $0.62 \mu$ in the lower region. In the distal part of the secondary cell the granules are hollowed or empty, and are of the same size as in the other species. The granules in the distal tip of the retinula extend further down towards the base, in the bulbous part of which the granules are larger, i.e. with diameters of $0.33 \mu$. The mutants $v, p r$ and se of $D$. pseudoobscura present submicroscopic pictures very similar to those of the homologous mutants $\nu$, bw and se of $D$. melanogaster, with the exception that in se all the granules are smaller than in the wild type, instead of larger.

\section{DISCUSSION}

Both the ommochrome and the pterin are deposited in granules as chromophores derived from the brown (3-hydroxykynurenine) and red (pteridine) chromogens respectively, and are assumed to be bound to proteins or polypeptides. The function of the locus of brown has been assumed to be the combination of the red chromogen with substrate to form the chromophore (Nolte, I952). The mutant bw produces no drosopterin (Hadorn and Mitchell, I95I), but Hadorn and Ziegler-Günder (1958) have demonstrated that this mutant gene influences the production of pteridines such as IX, HB and SP which are found in the head in early pupal stages, reaching maximum amounts at the time when DP production is starting in the wild type eye; these substances are excreted during metamorphosis, mainly in the meconia (Hadorn and Kürtsteiner, I956). Since no granules are present in the distal part of the secondary cell, the locus of brown can be conceived as being active in the transformation of one or other of these pteridines into a precursor of drosopterin.

The locus of vermilion acts in the transformation of formylkynurenine into kynurenine, while the locus of scarlet has been assumed to control the formation of the brown chromophore from the 3hydroxykynurenine (Nolte, I954a). Electron micrographs show that the mutant alleles of these two genes do not completely block ommochrome production.

In the mutant se the yellow pigment, sepiapterin or SP, replaces drosopterin or DP, while in the mutant $c l$ only a part of the drosopterin is replaced (Nolte, I954b). The comparative measure for sepiapterin in se, absorbing at $4 \mathrm{I} 5 \mathrm{~m} \mu$, is $0.3708 \pm 0.0050$. Hadorn and ZieglerGünder (1958) found in se about twenty times as much SP and about ten times as much $\mathrm{HB}$ as are produced in the wild type. This would mean that in the wild type there should occur about $0.02 \mathrm{SP}$ as measured at $4 \mathrm{I} 5 \mathrm{~m} \mu$, as compared with about $0.90 \mathrm{DP}$ as measured at $480 \mathrm{~m} \mu$. The fact that in the mutants se and $c l$ more brown pigment is deposited than in the wild type, led to the conclusion that the normal genes of these mutants act on a basic precursor common to the two pigments (Nolte, I $954 b$ ). On the basis of later investigations wherein the effect of polygenes on pigment amounts in the wild type and eye-colour mutants was demonstrated (Nolte, I959c) it could 
now be argued that this excess of brown pigment is independent of the direct action of these mutations. However, the electron micrographs show that in se all granules with brown pigment are larger than in the wild type, that in the Graaff-Reinet strain, with as much brown pigment as se, the brown pigment granules remain more or less normal in size, and that in $c l$, with more brown pigment than se, only the primary cell and retinular basal granules are larger than normal. These two mutants then show some effect of the mutant genes on brown pigment granules or on pigment granule structure -in se the red pigment granules are also larger than normal. SP is assumed to be in the direct line of DP (Forrest and Mitchell, 1955). Hadorn and Ziegler-Günder (1958) have shown that the HB-pteridines start increasing in amount slightly earlier than DP and SP but that these two are formed more or less concurrently. In se the SP increases to the sixth day of adult life, and in the wild type DP increases to the third day. The small undissolved granules in the distal part of the secondary cell of the pupa are very similar in electron density to the granules in that region in se adults. It can be visualised that in the wild type some SP is deposited first in the young granules of the secondary cell. In se no DP is formed from the SP so that ultimately the excess of the latter is deposited in these granules which normally take up DP; in $c l$ this process takes place partly only. The loci of sepia and clot thus seem to be active in the conversion of pteridines into red pigment, and the effect on granule size, especially in the case of se, seems to be a secondary effect.

The mutants $p$ and $m a h$ are seen to affect the pigment granule. In $p$ both pigment amounts are lower than normal by about twothirds, while in mah only the red pigment has been reduced by about one-third. The function of the locus of pink has been assumed to lie in the production of a basic constituent of both pigments (Nolte, 1955), but it now seems more probable that the mutant gene somehow interferes with the method of deposition of the two pigments or with the diffusion of the chromogens into and through the pigment cells, so that the quantitative effects may be secondary. In mah the reduced red pigment amount may result from a decrease in deposition on the decreased surface area of granules in the secondary cells: the normal allele of mahogany can be assumed to play a role in pigment granule production.

The mutants $p n$ and $r a s^{2}$ affect the differentiation and orientation of the basal regions of the secondary cells, but not of basal pigment cells (Nolte, I $959 b$ ). These bases appear to be lifted away from the basement membrane, and if deposition spreads outwards in a wave from the basement membrane, the decreased red pigment content could be a secondary effect. However, in both mutants the granules in the distal part of the secondary cell are not dissolved away as in the wild type, but consist of a medium-dense material which shows a roughish fuzzy outline as if some measure of solution 
had taken place, perhaps during the preparation of the material. Though denser, the rest of the secondary cell granules are of a similar type in $\mathrm{ras}^{2}$, and the exceptional reddish violet colour of the granules (Nolte, 1950) and the modified spectrophotometric curve of the red pigment extract in the ultraviolet (Nolte, $1959 b$ ) are further indications of a qualitatively different pigment. Evidence for different red pigments has been advanced by Viscontini, Hadorn and Karrer (1957) who found neodrosopterin to be the least water-soluble and with a spectrophotometric curve slightly different to that of the other two components. The normal allele of raspberry seems to be active in the production of some basic substance which affects both cell and chromophore development. The normal allele of prune appears to be active during histological differentiation, perhaps during the differentiation of the retinulæ and secondary pigment cells.

The eye pigments of the multiple alleles at the white locus have been investigated spectrophotometrically in order to assess their qualitative and quantitative differences (Nolte, I959a). In the present study it is seen that granules with ommochrome only occur at more or less the normal frequency but that the sizes of the primary cell and retinular base granules are correlated with pigment amount. The red pigment granules in the distal part of the secondary pigment cell occur in reduced numbers as compared with the wild type in the higher members of the series. In the lower members of the series the decrease in red pigment content is correlated with an increase in size, or number, of medium electron-dense masses, very often compound in structure. In the two lightest members, $w^{t}$ and $w$, these granular masses are also found in the basal part of the secondary cell, while similar, though smaller granules occur in the primary cells. In members with a higher red pigment content there are apparently two kinds of granules in the distal part of the secondary cell, differing from the normal in that one kind is medium electrondense, with an uneven fuzzy outline, while the other is smaller and denser but not showing hollows, excepting in $w^{c 0}$. The more electrondense granules may contain the drosopterin while the less dense granules may be the equivalent of those found in such alleles as $w^{e}$. Hadorn and Mitchell (I95I) have shown that whereas w which possesses no drosopterin, also has no subsidiary pteridines, the alleles $w^{a}$ and $w^{e}$, with some drosopterin, also have some of these pteridines. It has also been shown by Hadorn and Ziegler-Günder (1958) that in $w$ considerable amounts of the other pteridines are produced in the eyes during the pupal stages; the amounts, however, decrease and finally disappear, being excreted in the meconia. The heterogeneity of the red pigment has been suggested by Ephrussi (1945), and the differences between the alleles in their spectrophotometric curves have been mentioned by Nolte (1959a). It has also been noted that drosopterin has been separated into three components, of which neodrosopterin is yellow-fluorescing instead of orange-fluorescing 
and has a solubility different to that of the other two components. The small denser granules in white alleles may be one of the subsidiary drosopterins, but the larger less dense granules could not contain a drosopterin, since they occur in eyes with no pteridines. Although the pterin and ommochrome are so unrelated that the visualisation of a common step in their production is difficult, it has been postulated, on the basis of certain evidence that the normal allele of the white locus functions in the differentiation of a common substrate into substances required for the production of the red and the brown chromophores (Nolte, I959a). The suggestion by Kühn (1956) that ommochromes and pteridines might compete with regard to sites of reaction in granules, does not apply because in these mutants the amount of brown pigment is generally decreased in the primary cell, where normally no red pigment is deposited.

It now appears that the locus of white must act in the chain of reactions leading to the production of the pteridines, and if the ommochrome chain of production is connected with this, it would probably only be through the pteridines. Forrest and Mitchell (I955) have suggested that this inter-relationship could be reconciled with the chemical dissimilarity of the two substances if one of the pteridines acted as a coenzyme or moderator of enzyme reactions connected with the synthesis of the brown pigment. The medium electrondense masses in the pigment cells of the lower members of the white series of multiple alleles is probably an accumulation of some substance necessary for combination with the red and brown chromophores.

It has been known for some time that pseudoalleles occur at the white locus, and Green (I959) has advanced evidence that the alleles at this locus assort spatially and functionally into at least two groups. He further states, however, that all spatial loci are functionally integrated to produce a single product, each contributing slightly differently to the integrated product. The present study shows only a graded series of structural elements correlated with pigment content decreases. Although in all sections of $w^{e}, w^{t}$ and $w$ an abnormality has been found in the rhabdomeres in that oblong slits occur at intervals between the regular stacks of tubules or rods, this could be an artifact. If the abnormality is real, the problem is not clarified since, although $w^{e}$ and $w$ belong to one spatial locus, the rhabdomeres of $w^{\text {ch }}$ are normal, and yet this allele is thought to belong to the same spatial group.

The small retinular granules in Drosophila were first noted in $D$. virilis by Yasuzumi and Deguchi (1958), the size varying from 0.09 to $0.18 \mu$; the large pigment granules, size $0.44-0.60 \mu$, were presumed to be shrunken as a result of fixation or dehydration. In the present study the small ommochrome granules in the distal parts of the retinulæ of $D$. pseudoobscura are of the same size as in $D$. melanogaster, but the granules in the dilated retinular bases are somewhat larger than in the latter species. The primary cells contain brown pigment 
only since in the mutant $v$ granules are absent in this region. In a previous publication (Nolte, I958) it was stated that $D$. melanogaster differed from $D$. pseudoobscura in that red pigment was also deposited in the primary cells of the former: this is apparently not the case. The granules in the lower part of the primary cell are larger in $D$. pseudoobscura than in the other species, and the average amounts of brown pigment are 0.I9 as compared with 0.Io. Another difference is that the granules in the secondary cell bases are often more hollowed in $D$. pseudoobscura, although the red pigment contents average 0.9 as compared with $I \cdot 0$. The method of pigment deposition in $D$. pseudoobscura appears to be essentially similar to that in the other species, that is, in the main part of the secondary cell both pigments are laid down in the same granule, which agrees with the statement of Cochrane (1936) that during the late phase of pigment deposition the orange granules in the secondary cell enlarge and turn red, but not with the statement that during the later part of the early phase red granules appear among the brown.

\section{SUMMARY}

The location, structure and composition of the granules carrying deposits of the red and brown pigments were studied in the eyes of Drosophila by means of the electron microscope. The investigation included the adult, and in some cases the pupal, eyes of two wild and twenty mutant strains of $D$. melanogaster, and two wild and three mutant strains of $D$. pseudoobscura.

I. In both species the brown pigment or ommochrome is located in large granules in the primary pigment cells and in somewhat smaller granules in the middle and basal regions of the secondary pigment cells and in the post-retinal region. It is also located in very small granules, concentrated next to the rhabdomeres in the distal tips of the retinulæ, and in somewhat larger granules in the bulbous bases of the retinulæ which block the fenestrations in the basement membrane.

2. The red pigment or drosopterin is located, unmixed, in large granules in the distal tips of the secondary pigment cells and mixed with, or added on to, the ommochrome granules of the middle and basal regions of the secondary cells and of the post-retinal region.

3. In eye-colour mutants the following are some of the important modifications. In bw no granules occur in the distal tips of the secondary cells. In st and $v$ no ommochrome granules occur apart from few small granules in the primary cells of $v$ and a few in the retinulæ distally in st but basally in $v$. In se all granules are larger than normal and drosopterin is replaced by sepiapterin; in $c l$ only the ommochrome granules are larger than normal. In $p$ some of the granules carrying both pigments are enlarged and show a dense core inside a less dense cortex. In mah all granules are reduced in number but much larger than normal. In $p n$ both secondary cells and 


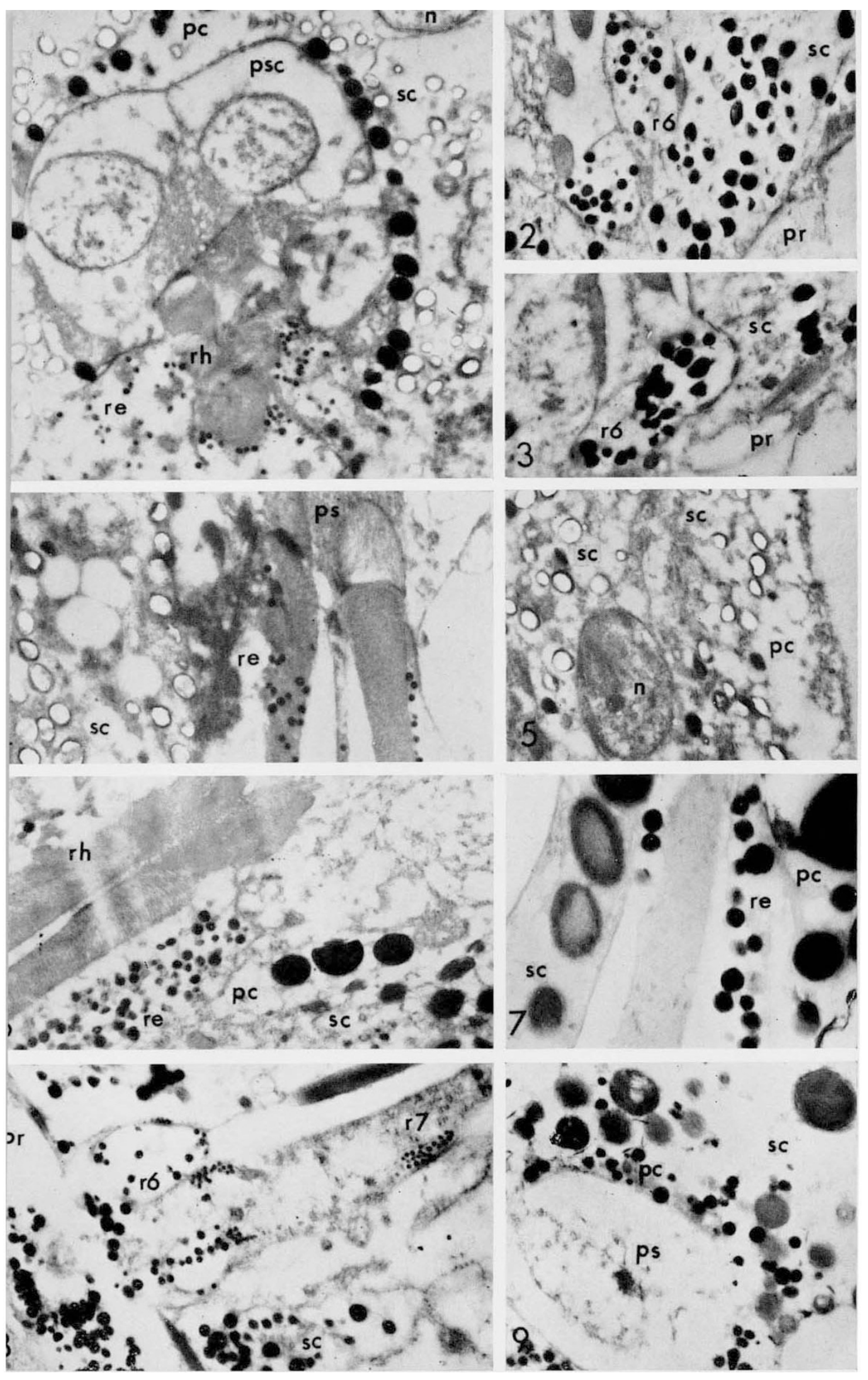




\author{
$n$, nucleus of secondary cell \\ $p c$, primary pigment cell \\ $p r$, post-retinal region \\ $p s$, pseudocone \\ psc, pseudocone cell
}

\author{
$r 6$, bases of six normal retinulæ \\ $r 7$, base of seventh, displaced, retinula \\ $r e$, retinula \\ $r h$, rhabdomere \\ $s c$, secondary pigment cell
}

FIG. I.-Oblique transverse section of an ommatidium of the wild type. Two pseudocone cells encircle the crystalline matter of the pseudocone. This is in contact with the tips of the rhabdomeres. The electron-dense granules of the primary pigment cells contain ommochrome and so do the small granules of the retinula tips. The hollows in the secondary pigment cells contained drosopterin. $\times 10,000$.

Fig. 2.-Oblique transverse section of the basal region in the wild type. Two dilated bases of retinulæ and three rhabdomeres of one rhabdome are seen. $\times 9600$.

Fig. 3.-The basal region in the wild type pupa, showing one retinula with its rhabdomere and dilated base with ommochrome granules. $\times$ I I, ooo.

FIG. 4.-A longitudinal section of the distal parts of the rhabdome of the mutant st. A few ommochrome granules occur in the distal tips of the retinulæ, while in the secondary pigment cell some of the emptied drosopterin granules are larger than normal $\times 8300$.

Fig. 5.-Primary and secondary pigment cells in the mutant $v$, with a few small ommochrome granules in the primary cell, and granules more or less emptied of their drosopterin in the secondary cells. $\times 12,000$.

FIG. 6.-The region around the distal parts of the rhabdome of the mutant se. The amorphous tips of the rhabdomeres are seen in the upper part. The ommochrome granules of the primary cell and the retinula tip are larger than normal, while the granules of the secondary cell are intermediate in density; they contain a yellow pigment, sepiapterin. $\times \mathrm{I}_{4}$, 000 .

Fig. 7.-The region near the pseudocone of the mutant mah shows the great increase in size of all granules. $\times$ I I,200.

Fig. 8.- The basal region in the allele $w^{\text {col }}$ with the ommochrome granules in the bases of the six normal retinulæ smaller than in the other multiple alleles of this locus, and the granules in the base of the seventh or displaced retinula smaller than normal but occurring in greater numbers. $\times 9000$.

Fig. 9.-The region around the pseudocone in the allele $w^{a}$ with small ommochrome granules in the primary cell and large compound granular masses in the distal part of the secondary cell. $\times 900$. 
retinulæ are disarranged, while in $\operatorname{ras}^{2}$ the secondary cells are drawn into bulges and the red pigment appears to be modified. In the alleles of $w$ the sizes of primary cell and retinula basal granules are more or less correlated with decrease in ommochrome content. In the lower members of the series aggregated granular masses appear in the secondary cell: these granules are composed of neither ommochrome nor drosopterin since in the lightest members they also appear in the primary cells.

Acknowledgments.-The author wishes to express his indebtedness to $\mathrm{Mr} \mathrm{J}$. W. Matthews of the Department of Physics, University of the Witwatersrand, for his assistance in the making of the electron micrographs.

\section{REFERENCES}

BEADLE, G. W., AND EPHRUSSI, B. 1936. The differentiation of eye pigments in Drosophila as studied by transplantation. Genetics, 2I, 225-247.

BEADLE, G. W., AND EPHRUSSI, B. 1937. Development of eye colours in Drosophila: diffusible substances and their interrelations. Genetics, 22, 76-81.

BECKER, E. 1942. Über Eigenschaften, Verbreitung und die genetischenentwickelungsphysiologische Bedeutung der Pigmente der Ommatin- und Ommingruppe (Ommochrome) bei der Arthropoden. Z. indukt. Abstamm.-u. Vererblehre, 8o, 157-204.

CASPARI, E. 1949. Physiological action of eye colour mutants in the moths Ephestia kühniella and Ptychoda seriata. Quart. Rev. Biol., 24, 185-199.

CLAYTON, F. E. 1959. The effect of lozenge pseudoalleles on eye pigmentation in Drosophila melanogaster. III. Pigment development during pupal differentiation. Genetics, 44, 1041-1052.

COCHRANE, F. 1936. An histological analysis of eye pigment development in Drosophila pseudoobscura. Proc. Roy. Soc. Edin., 57, 385-389.

EPHRUSSI, B. I945. Studies of eye pigments in Drosophila. III. The heterogeneity of the red "pigment" as revealed by the effects of the "white" alleles and by colour changes during development. Genetics, 30, 71-83.

FORREST, H. S., AND MITCHEll, H. K. 1954. Pteridines from Drosophila. II. Structure of the yellow pigment. 7. Amer. Chem. Soc., 76, 5658-5662.

FORREST, H. S., AND MITChell, H. K. 1955. Pteridines from Drosophila. III. Isolation and identification of three more pteridines. 7. Amer. Chem. Soc., 77, $4865-4869$.

GREEN, M. M. I949. A study of tryptophan in eye colour mutants of Drosophila. Genetics, 34, 564-572.

GREEN, M. M. I 959. Spatial and functional properties of pseudo-alleles at the white locus in Drosophila melanogaster. Heredity, 13, 303-315.

HADORN, E., AND KÜRTSTEINER, R. 1956. Unterschiede in Exkretstoffen bei verschiedenen Genotypen von Drosophila melanogaster. Arch. Ful. Klaus-Stiftg., 30, 494-498.

hadoRN, E., AND MTtChell, H. K. 195I. Properties of mutants of Drosophila melanogaster and changes during development as revealed by paper chromatography. Proc. Nat. Acad. Sci. (Wash.), 37, 650-665.

HADORN, E., AND ZIEGLER-GÜNDER, I. 1958. Untersuchungen zur Entwicklung, Geschlechtspezifität und phänogenetischen Autonomie bei Augenpterine verschiedener Genotypen von Drosophila melanogaster. Z. indukt. Abstamm.-u. Vererblehre, 89, 221-234.

кÜнN, А. 1956. Versuche zur Entwicklung eines Modells der Genwirkungen. Naturwissenschaften, 43, 25-28. 
NoLTE, D. J. 1950. The eye-pigmentary system of Drosophila: the pigment cells. 7. Genet., 50, 79-99.

NOLTE, D. J. 1952. The eye-pigmentary system of Drosophila. III. The action of eye-colour genes. F. Genet., 5I, 142-186.

NoLTE, D. J. 1954a. The eye-pigmentary system of Drosophila. IV. The pigments of the vermilion group of mutants. 7. Genet., 52, 11 1-126.

NoLTE, D. J. 1954b. The eye-pigmentary system of Drosophila. V. The pigments of the light and dark groups of mutants. F. Genet., 52, 127-139.

Nolte, D. J. I955. The eye-pigmentary system of Drosophila. VI. The pigments of the ruby and red groups of mutants. 7. Genet., 53, 1-io.

NoLTE, D. J. 1958. Eye pigment relationships in three species groups of Drosophila. Evolution, 12, 519-531.

NoLTE, D. J. 1959a. The eye-pigmentary system of Drosophila. VII. The white locus. Heredity, 13, 2 19-231.

Nolte, D. J. 1959b. The eye-pigmentary system of Drosophila. VIII. Series of multiple alleles. Heredity, 13, 233-241.

NoLTE, D. J. 1959c. Polygenes in eye pigment production in Drosophila species. Evolution, $13, \mathrm{I}-8$.

Nolte, D. J. 1961. Submicroscopic structure of the drosophilid eye. S. Afr. Fourn. Sci., 57 (to be published).

TAIRA, T., AND NAWA, s. 1958. No direct metabolic relation between pterines and uric acid, flavins or folic acid in Drosophila melanogaster. Fap. Fourn. Genet., $33,42-45$.

VISCONTINI, M., HADORN, E., AND KARRER, P. 1957. Fluoreszierende Stoffe aus Drosophila melanogaster: die roten Augenfarbstoffe. Helv. Chim. Acta, 40, 579-585.

VISCONTINI, M., LOESER, E., KARRER, P., AND HADORN, E. 1955. Fluoreszierende Stoffe aus Drosophila melanogaster II. Helv. Chim. Acta, 38, I 222-1 224, 2034-2035. VISCONTINI, M., SGHOELLER, M., LOESER, E., KARRER, P., AND HADORN, E. 1955 . Isolierung fluoreszierender $\mathrm{Stoffe}$ aus Drosophila melanogaster. Helv. Chim. Acta, 38, 397-401.

YASUZUNI, G., AND DEGUCHI, N. 1958. Submicroscopic structure of the compound eye as revealed by electron microscopy. F. Ultrastruct. Research, I, 259-270.

ZIEgleR-GÜNDER, I. 1956. Pterine: Pigmente und Wirkstoffe im Tierreich. Biol. Rev., 3I, 313-348.

ZIEGLER-GÜNDER, I., AND HADORN, E. 1958. Manifestation rezessiver Augenfarbgene im Pterininventar heterozygoter Genotypen von Drosophila melanogaster. Z. indukt. Abstamm.-u. Vererblehre, 89, 235-245. 